\title{
FINANCIAL RATIO ANALYSIS IN PREDICTING FINANCIAL CONDITIONS DISTRESS IN INDONESIA STOCK EXCHANGE
}

\author{
Mesak Dance*, Sukartha I Made \\ University of Udayana, Denpasar, Indonesia \\ ${ }^{*}$ E-mail: dames.j.hope@gmail.com
}

\begin{abstract}
Financial distress is a condition where a company experiences financial difficulties, if these conditions cannot be overcome; it is possible that the company will experience bankruptcy. This research was conducted to reexamine some of the differences in the results of previous studies and models in identifying financial distress conditions, the phenomenon of delisting companies from the Indonesia Stock Exchange (IDX) and research objects, so researchers were interested in reexamining the effect of financial ratios on financial distress. The purpose of this research is to analyze the effect of liquidity ratios, profitability, financial leverage and operating cash flows on the condition of financial distress companies that listed on the Indonesia Stock Exchange. This research was conducted at companies listed on the Indonesia Stock Exchange (IDX) which provide annual financial report data by downloading on the official website of the Indonesia Stock Exchange (IDX) through the website www.idx.co.id. The type of data used in this research is Quantitative data is data in the form of numbers obtained from the Indonesia Stock Exchange such as the 2013-2017 financial statements. This study uses secondary data sources. The variables used in this study are liquidity ratios, profitability, financial leverage, and operating cash flows as independent variables and financial distress as dependent variable. Testing the hypothesis in this study uses logistic regression. Based on the results of logistic regression analysis with a significance level of $5 \%$, the results of this study indicate that (1) the liquidity ratio measured by the current ratio $(\mathrm{CR})$ has a negative effect on the condition of corporate financial distress listed on the Indonesia Stock Exchange; (2) profitability ratios measured by Return On Assets (ROA) negatively affect the condition of financial distress companies listed on the Indonesia Stock Exchange; (3) financial leverage ratio measured by Debt to Equity Ratio (DER) has a positive effect on the condition of corporate financial distress listed on the Indonesia Stock Exchange; (4) the ratio of operating cash flow has no effect on the condition of the company's financial distress listed on the Indonesia Stock Exchange.
\end{abstract}

\section{KEY WORDS}

Financial distress, liquidity, profitability ratio, financial leverage ratio, operating cash flow.

Financial distress is a condition where a company experiences financial difficulties, if these conditions cannot be overcome; it is possible that the company will run into bankruptcy. Therefore by knowing the condition of the company's financial distress from the outset it is expected that actions can be taken to anticipate conditions that lead to bankruptcy. To measure the financial distress of a company is done by analyzing financial statements. According to Irham Fahmi (2015: 2), explained that: "Financial statements are information that describes the financial condition of a company, and further information can be used as an illustration of the company's financial performance. Financial statements can also be used as a tool in making projections regarding various financial aspects of a company in the future.

To find out the symptoms of bankruptcy, a model is needed to predict financial distress conditions to avoid losses in investing. One important aspect of the analysis of financial statements of a company is to predict the continuity or going concern of the company, therefore it is very important for management and company owners to anticipate the possibility of potential bankruptcy. 
This research was conducted to reexamine several factors in previous research that influenced the condition of corporate financial distress because in previous studies the results obtained there were different as in the research from Platt and Platt (2002) showed that liquidity ratios had a negative relationship with the possibility of companies experiencing financial distress. Whereas in the Srikalimah (2017) study, liquidity has a positive effect on the company's financial distress. Because the greater the liquidity ratio, the smaller the company will experience financial distress. Research conducted by Wahyu Widarjo \& Doddy Setiawan (2009) profitability (ROA) has no effect in predicting financial distress conditions while Imam Masud \& Reva Maymi Srengga (2011) has an influence on predicting financial distress. while research from Imam Masud \& Reva Maymi Srengga (2011) shows that leverage (DER) has no effect in predicting financial distress conditions while Tio Noviandri (2013) leverage (DER) influences predicting financial distress conditions. In the research of Imam Ma'ud Reva Maymi Srengga (2011) results show that operating cash flow has an effect on financial distress while according to Wahyuningtyas (2010) found that information on cash flow values has no effect in predicting financial distress conditions.

In addition, the previous research was different from this study, where previous research in identifying the causes of a company experiencing conditions of financial distress using the Neoclassical Model. In this model bankruptcy occurs if the allocation of resources is not appropriate. This case of restructuring occurs when a bankruptcy has a mixture of wrong assets. Estimating difficulties is done with balance sheet data and income statement. For example profit / assets (to measure profitability) and assets liabilities. While this research uses a Financial Model where this model estimates difficulties with financial indicators or performance indicators such as total assets, revenues / turnover, return on assets, return on equity, profit margins, stock turnover, receivables turnover, cash flow / total equities. , debt ratio, cash flow (liabilities-reserves), current ratio, acid test, current liquidity, short term assets / daily operating expenses, gearing ratio, turnover per employe, coverage of fixed assets, working capital, total equity per share, earnings per share ratio.

The condition of financial distress also occurs in companies listed on the Indonesia Stock Exchange (IDX). The phenomenon of delisting of companies from the Indonesia Stock Exchange (IDX) is analyzed from various sides, one of which is a model for predicting companies that experience financial difficulties up to the category of bankruptcy. One of the reasons for companies being delisted from the Indonesia Stock Exchange (IDX) is that the company suffered a loss of 2 (two) years in a row and was unable to pay short-term debt to investors or creditors. The reason that caused the company to experience financial distress. Companies that are delisted from the Indonesia Stock Exchange (IDX) up to 2018 are 39 companies. Companies that are delisted from the Indonesia Stock Exchange (IDX) are caused by several factors including through the voluntary company's wishes by reason of acquisitions, mergers.

\section{LITERATURE REVIEW}

According to Husnan (2014: 7) interpreting the value of the company as the price that prospective buyers can afford when the company is sold. When a company has opened or has offered shares to the public, the company's value is interpreted as an investor's perception of the company itself. Investors can use company value as a basis to see the company's performance in the coming period, where company value is often associated with stock prices. A high corporate value will increase an investor's trust in the company.

Based on Jogiyanto (2000: 392) states that information published to the public as an announcement will provide a signal for users of financial information in decision making. Information received by investors is first translated as a signal that is good (good news) or a bad signal (bad news).

According to Irham Fahmi (2015: 2), explained that: "Financial statements are information that describes the financial condition of a company, and further information can be used as an illustration of the company's financial performance. Financial reports according to Kasmir (2012: 27) are "reports that show the company's financial condition at 
this time or in a certain period". Based on the opinions of the experts, it can be seen that the financial statements provided by the management of the company are very helpful for those who need financial information to make decisions and further describe the company's financial performance.

According to Kasmir (2016: 104) financial ratio is an activity comparing the numbers in the financial statements by dividing one number by another. Comparisons can be made between one component and the components in one financial report or among components in the financial statements, then the comparable numbers can be in the numbers in a period or several periods. Based on the explanation above, financial ratios are a comparison of the number of components contained in financial statements, both in one period and several periods and then used as material for analysis. According to Kasmir (2016: 110-114), the forms of financial ratios are as follows: "Liquidity ratio, leverage ratio, activity ratio, profitability ratio, growth ratio and valuation ratio".

According to Darsono and Ashari in his book "Practical Guidelines for Understanding Financial Statements" (2005: 91), the ratio analysis tool for cash flow statements needed to assess the company's financial performance includes: Cash Flow Liquidity Ratios, and Cash Flow Flexibility Ratios.

Munawir (2004: 22) defines financial distress or bankruptcy as the failure of the company to carry out the operations of the company to generate profits and also as a liquidation of the company (closure of insolvency companies).

\section{DEVELOPMENT OF HYPOTHESES}

The variable contribution of liquidity in the aspect current ratio $(C R)$ in increasing the value of the company can be stated that, these ratios provide an overview of the company's ability to fulfill its short-term obligations, where the greater the percentage current ratio (CR), the company has a liquidation rate good and will increase the value of the company, thus the company will provide a positive signal to investors for the prospects of the company so that investors will be interested in investing their shares in the company. In a study conducted by Atika et al. (2013) on the Effect of Some Financial Ratios on Predictions on the Condition of Financial Distress (Study of Textile and Garment Companies Listed on the Indonesia Stock Exchange in the period 2008-2011), the results of the study showed that the liquidity ratio had a negative effect on financial distress condition. The greater the comparison of current assets with current debt, the higher the company's ability to cover its short-term liabilities and vice versa if the comparison is getting lower then the company cannot afford to pay its shortterm debt.

$H_{1}$ : liquidity has a negative effect on financial distress.

The existence of ROA growth shows that the company's prospects are getting better because it means that there is a potential increase in profits gained by the company, this means it will increase the value of the company. This is captured by investors as a positive signal from the company so that it will increase investor confidence and will make it easier for company management to attract capital in the form of shares. If there is an increase in the demand for shares of a company, it will indirectly increase the price of the stock in the capital market. Orina Andre (2013), Effect of Profitability, Liquidity and Leverage in Predicting Financial Distress in Various Industry Companies on the IDX. The results of this study conclude: profitability has a negative and significant influence in predicting financial distress in various industrial companies listed on the Indonesia Stock Exchange. The greater the ROA results, the better the company's performance. The increasing ratio shows that management performance increases in managing operational funding sources effectively to generate net income (profitability increases). Based on these opinions, the hypothesis can be presented in this study:

$\mathrm{H}_{2}$ : profitability has a negative effect on financial distress.

Based on signal theory According to Jogiyanto (2000: 392) states that information published to the public as an announcement will provide a signal for users of financial information in decision making. So the lower the Debt to Equity Ratio it will increase the 
value of the company, this will provide a good signal for investors. Research conducted by Orina Andre (2013), Effect of Profitability, Liquidity and Leverage in Predicting Financial Distress in Various Industry Companies on the IDX. Based on the results of his research shows that leverage has a positive and significant influence in predicting financial distress. The higher the Debt to Equity Ratio, the smaller the profit distributed to shareholders, on the contrary the lower the Debt to Equity Ratio, the greater the profit received by the shareholders. A high Debt to Equity Ratio can reduce the value of the company, while a low Debt to Equity Ratio can increase the value of the company. Based on these opinions, the hypothesis can be formulated as follows:

$H_{3}$ : financial leverage has a positive effect on financial distress.

When the net cash flow ratio increases, the company's profits will increase and this will increase the value of the company and then also increase the company's profits so that the company will not experience financial distress, this will provide a good signal for investors. The ratio of net cash flow from operating activities divided by current debt can be used to predict the company's financial distress. The research conducted by Adinda Tria Ananda (2017) found that information on cash flow values had no effect in predicting financial distress conditions. This means that the lower the cash flow the company has, the more likely it is to experience financial distress. The higher the net operating cash flow value owned by the company, the company will not experience financial distress and will increase the value of the company and contrary if the lower the net cash flow value, the company will experience financial distress and will reduce the value of the company. Based on these opinions, the hypothesis can be presented in this study as follow:

$\mathrm{H}_{4}$ : Operating cash flow has a negative effect on the company's financial distress.

\section{METHODS OF RESEARCH}

The population in this study was all companies listed on the Indonesia Stock Exchange (IDX) in 2013-2017. The sampling technique in this research is sampling purpose with the following criteria:

- Companies that listed on the Indonesia Stock Exchange (IDX) in 2013-2017;

- The company that publishes annual reports with the reporting period per January to December year ends in a row from 2013-2017.

Dependent Variable ( $Y$ ). Financial distress is one of the interesting studies that continues to be studied both in terms of financial management and accounting. In this research the dependent variable is financial distress $(Y)$. This dependent variable is measured using the Zmijewski model. The formulas for this model are as follows:

$$
\text { X-score }=-4,3-4,5 X_{1}+5,7 X_{2}-0,004 X_{3}
$$

The financial ratios analyzed are financial ratios contained in the Zmijewski model, specifically:

$\mathrm{X}_{1}=\mathrm{EAT} /$ Total Assets $\times 100 \%$ (Return On Asset);

$\mathrm{X}_{2}=$ Total Debt / Total Asset x 100\%;

$\mathrm{X}_{3}=$ Current Asset / Current Liabilities.

The company classification of the Zmijewski model is based on a cutoff point of 0 (zero). If the X-Score value is below the cut-off point, the company is in a healthy condition. However, the X-Score is above the cut-off point, the company is in financial distress.

Independent Variables $(X)$ :

According to Fred Weston in the book Kasmir (2010: 129), said that liquidity (liquidity ratio) is a ratio that describes the company's ability to meet short-term obligations (debt). Current Ratio is a ratio that shows the extent to which current assets cover current liabilities. The greater the comparison of current assets with current debt, the higher the company's ability to cover its short-term liabilities (Sofyan Syafri Harahap, 2013: 301).

In the opinion of Kasmir (2010: 196), said that the ratio of profitability ratios is a ratio to assess the company's ability to seek profits. This ratio also provides a measure of the 
management effectiveness of a company. Return on Assets (ROA) is one of the profitability ratios. In financial statement analysis, this ratio is most often highlighted, because it is able to show the success of the company to make a profit.

Financial leverage shows the company's ability to fulfill obligations both for short and long term. Analysis of this ratio is needed to measure a company's ability to pay debts (short and long term) if at one time the company is liquidated or dissolved (Sigit, 2008). The indicator used to measure the level of corporate financial leverage in this study is total debt divided by total capital (Debt to Equity Ratio).

The Operational Cash Flow Ratio calculates the ability of operating cash flows to pay current liabilities. This ratio is obtained by dividing operating cash flows with current liabilities.

Based on the explanation above, the research model is as follows:

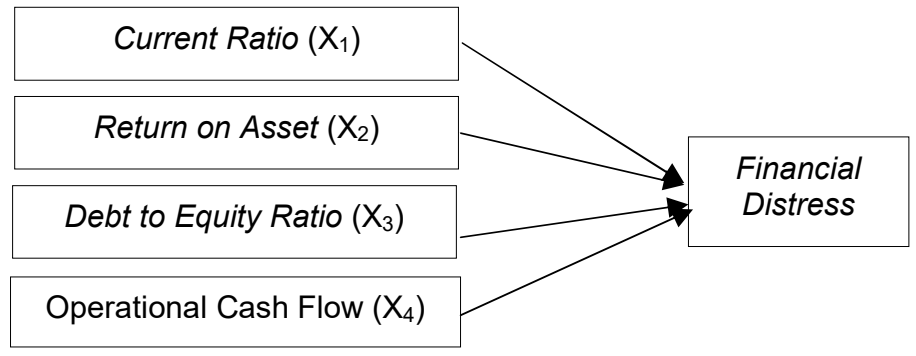

Figure 1 - Research Model

Data collection methods used in this study includes documentation, namely data collection techniques carried out by the author through documents relating to the problem under study such as financial statements. The type of data used in this study is secondary data. Secondary data is data collected in the form of documents or literature in the form of annual financial reports.

Testing the hypothesis in this study uses logistic regression to determine the predictive power of financial ratios and financial ratios, which are the most dominant in determining whether a company will going into financial distress or not. The use of logistic regression analysis is because the dependent variable is dichotomous (precise and inappropriate). The logistic regression equation model used in this study is as follows:

$$
\text { In } \frac{p}{1-p}=\beta \mathrm{o}+\beta 1 \mathrm{LK}+\beta_{2} \text { Profit }+\beta_{3} \text { Leverage }+\beta_{4} \mathrm{AKO}+£
$$

Where: Bo = constant; $\mathrm{LK}=$ Liquidity; Profit $=$ Profitability; Leverage $=$ Leverage; $\mathrm{AKO}=$ Operational Cash Flow; $£=$ error standard.

\section{RESULTS AND DISCUSSION}

Descriptive Statistics Analysis. Descriptive statistics explain the value of minimum, maximum, average and standard deviation for each variable. Descriptive statistical results can be seen in table 1 below.

Table 1 - Descriptive Statistic

\begin{tabular}{llllll}
\hline & $\mathrm{N}$ & Minimum & Maximum & Mean & Std. Deviation \\
\hline Financial Distress & 323 & 0 & 1 & 0.8 & 0.27 \\
Likuidity & 323 & 0.15 & 4.90 & 1.57 & 1.11 \\
Profitability & 323 & -0.13 & 0.45 & 0.03 & 0.05 \\
Leverage & 323 & 0.02 & 1.96 & 0.39 & 0.29 \\
Operational Cash Flow & 323 & -5.15 & 9.31 & 0.39 & 1.26 \\
Valid N (listwise) & 323 & & & & \\
\hline
\end{tabular}

Source: processed data, 2018. 
From the table above shows that the number of respondents $(N)$ is 323 , of the 395 respondents the value of each research variable is the Current ratio (X1) has a minimum value of 0.15 or $15 \%$ and a maximum value of 4.90 or $490 \%$ with an average amounting to 1.57 or $157 \%$ and standard deviation 1.11. Return On Asset (X2) has a negative minimum value of 0.13 or $13 \%$ and a maximum value of 0.45 or $45 \%$ with an average of 0.03 or $3 \%$ and a standard deviation of 0.05 . Debt to Equity Ratio (X3) has a minimum value of 0.02 or $2 \%$ and a maximum value of 1.96 or $196 \%$ with an average of 0.39 or $39 \%$ and a standard deviation of 0.29 . Operating Cash Flow (X4) has a negative minimum value of 0.15 or $15 \%$ and a maximum value of 9.31 or $931 \%$ with an average of 0.39 or $39 \%$ and a standard deviation of 1.26 .

Goodness of Fit Test. This test is needed to ensure there are no weaknesses in the conclusions of the model obtained. A good logistic regression model is if there is no difference between the observational data and the data obtained from the predicted results.

Table 2 - Hosmer and Lemeshow Test

\begin{tabular}{llll}
\hline Step & Chi-square & df & Sig. \\
\hline 1 & 8.438 & 8 & 0.392 \\
\hline
\end{tabular}

Source: Processed data, 2018.

From the table above the value of hosmer and glue test is greater than the value of 0.05 , whereas the logistic regression model is able to explain the data and there is no difference between the model and the value of its observations. This means that the model is able to predict the value of its observations or it can be said that the model is accepted because the model matches the results of its observations.

Table 3 - Accuracy of Predictions

\begin{tabular}{|c|c|c|c|c|c|}
\hline & \multirow{3}{*}{ Observed } & \multicolumn{3}{|c|}{ Predicted } \\
\hline & & & Y (Financial Distr & & Percentage Correct \\
\hline & & & $\begin{array}{c}\text { Not run into Financial } \\
\text { Distress }\end{array}$ & $\begin{array}{l}\text { Financial } \\
\text { distress }\end{array}$ & \\
\hline $\begin{array}{c}\text { Step } \\
1\end{array}$ & $Y$ & $\begin{array}{l}\text { Not run into Financial } \\
\text { Distress }\end{array}$ & 295 & 1 & 99.3 \\
\hline & & $\begin{array}{l}\text { Financial Distress } \\
\text { Overall Percentage }\end{array}$ & 23 & 3 & $\begin{array}{l}11.5 \\
92.3\end{array}$ \\
\hline
\end{tabular}

Source: Processed data, 2018.

From the table above shows the prediction model of the regression model to predict financial distress conditions at $92.3 \%$. By using the regression model, there are $296(99.3 \%)$ companies that do not need financial difficulties from a total of 323 companies sampled in the 2013-2017 research period while as many as $26(11.5 \%)$ companies experience financial difficulties.

Table 4 - Model Summary

\begin{tabular}{llll}
\hline Step & -2 Log likelihood & Cox \& Snell R Square & Nagelkerke R Square \\
\hline 1 & $141.801(a)$ & 0.114 & 0.266 \\
\hline
\end{tabular}

Source: processed data, 2018.

From the table above, it can be seen that the model by entering four independent variables turns out that there has been a change in parameter estimation with Log likelihood -2 value of 141,801 . If seen from the value of Cox \& Snell $R$ Square 0.114 or $11.4 \%$ and the Nagelkerke R Square value of 0.266 or $26.6 \%$. Thus it can be interpreted that with four variables, namely Current Ratio, Return on Asset, Debt Equity Ratio and Operating Cash Flow, the proportion in predicting financial distress conditions can be explained at $26.6 \%$ and the remainder is influenced by variables outside the study of $73.4 \%$. 
Table 5 - Omnibus Tests of Model Coefficients

\begin{tabular}{lllll}
\hline & & Chi-square & df & Sig. \\
\hline Step 1 & Step & 39.065 & 4 & .000 \\
& Block & 39.065 & 4 & .000 \\
& Model & 39.065 & 4 & .000 \\
\hline
\end{tabular}

Source: Processed data, 2018.

From the table above, it can be explained that the omnimus test of model coefficient with the number of independent variables of four variables produces a significant value of 0.000 lower than 0.05 . This shows that there is a significant effect of the independent variables simultaneously affecting the dependent variable.

Hypothesis test. Partial testing of the significance of predictors is done using the wald test and the chi square approach is obtained as follows:

Table 6 - Regression Analysis Results

\begin{tabular}{llllllll}
\hline & & B & S.E. & Wald & df & Sig. & Exp (B) \\
\hline Step & Liquidity & -0.822 & 0.312 & 6.961 & 1 & 0.008 & 0.439 \\
1 (a) & Profitability & -30.591 & 6.675 & 21.005 & 1 & 0.000 & 0.000 \\
& Leverage & 2.381 & 0.820 & 8.434 & 1 & 0.004 & 10.818 \\
& Operational Cash Flow & 0.108 & 0.177 & 0.375 & 1 & 0.540 & 1.114 \\
& Constant & -1.973 & 0.415 & 22.550 & 1 & 0.000 & 0.139 \\
\hline
\end{tabular}

Source: processed data, 2018.

Based on the results of the logistic regression analysis above, the regression equation is obtained as follows:

$$
\text { In } \frac{p}{1-p}=-1.973-0.822 \mathrm{LK}-30.591 \text { Profit }+2.381 \text { Leverage }+0.108 \mathrm{AKO}
$$

\section{DISCUSSION OF RESULTS}

Effect of Liquidity on Financial Distress Conditions. The results of data analysis shown in table 6 indicate that liquidity as measured by Current Ratio has a negative effect on financial distress with a significant level of 0.008 . This means that the greater the comparison of the value of current assets to current liabilities, the company will not experience financial distress. This shows that Hypothesis One $(\mathrm{H} 1)$ states that liquidity has a negative effect on the condition of financial distress in companies listed on the Indonesia Stock Exchange (IDX) accepted. Thus the results support the theory which states that the greater the current ratio, the company will not experience financial distress. Therefore the company that is the sample in this study is able to properly manage current liabilities with current assets so that the company does not experience financial distress. Based on the results of the analysis and explanation above, it can be concluded that the higher the value of a company's liquidity ratio, the company will not experience financial distress and will increase the value of the company and provide a good signal to the capital market. The results of this study are consistent with the research conducted by Atika, et al. (2013) where the results of the study indicate that financial ratios that have an influence to predict financial distress conditions are Current ratios negatively affect financial distress with beta values of $-8,939$.

Effect of Profitability on Financial Distress Conditions. The results of the data analysis shown in table 6 indicate that the profitability measured by Return on Assets (ROA) has a negative effect on financial distress conditions with a significant level of 0.000 . This means that the greater the value of profitability produced by the company, the company will not experience financial distress. This means that Hypothesis Two $(\mathrm{H} 2)$ which states that profitability has a negative effect on the condition of financial distress in companies listed on the Indonesia Stock Exchange (IDX) is accepted. Thus the results support the theory which 
states that the greater the value of profitability of a company, the company will not experience financial distress. It means that the greater the value of the profitability produced by the company will increase the value of the company and provide a positive signal for the capital market so that the company will not experience financial distress and vice versa if the profitability of a company decreases and reduces the value of the company and the company will experience financial distress. Based on the results of the analysis and explanation above, it can be concluded that the greater the value of profitability produced by a company, the company will not experience financial distress so that it will increase the value of the company and provide a good signal to the capital market. The results of this study are consistent with research conducted by Orina Andre (2013) where the results of this study conclude: profitability has a negative and significant influence in predicting financial distress in various industrial companies listed on the Indonesia Stock Exchange.

The Effect of Financial Leverage on Financial Distress Conditions. Based on the results of the analysis shown in table 3.6 Shows that financial leverage as measured by Debt to Equity Ratio (DER) has an effect on the condition of financial distress with a significant level of 0.004. This means that the greater the value of the Debt to Equity Ratio (DER) owned by the company, the better the company will experience financial distress conditions. This shows that the Third Hypothesis $(\mathrm{H} 3)$ states that financial leverage has a positive effect on accepted financial distress. Thus the results support the theory which states that the greater the value of Debt to Equity Ratio (DER), the company will experience financial distress. It means that the higher the value of financial leverage that a company has will reduce the value of the company and provide a negative signal for the capital market so that the company will experience financial distress and vice versa if the value of financial leverage of the company decreases will increase the value of the company and provide positive signals for the capital market the company will not experience financial distress. Based on the results of the analysis and explanation above, it can be concluded that the higher the value of financial leverage of a company, the company will experience financial distress so that it will reduce the value of the company and provide a bad signal to the capital market. The results of this study are consistent with the research conducted by Luciana and Kristijadi (2003). The results of this study indicate that financial ratios mentioned that financial leverage ratios, namely the variable total debt divided by total capital (DER) can be used to predict financial distress of a company. Because the greater the ratio of financial leverage, the more likely the company experiences financial distress. The coefficient in this variable is positive, meaning that the DER variable has a positive influence on a company's financial distress.

Effect of Operating Cash Flow on Financial Distress Conditions. The results of data analysis shown in table 3.6 indicate that operating cash flows have no effect on financial distress conditions with a significant value of 0.540 . Thus the fourth hypothesis $(\mathrm{H} 4)$ which states that operating cash flow has a negative effect on the condition of corporate financial distress is rejected. This means that operating cash flow cannot be used in predicting the company's financial distress sample in this study. The results of this study are consistent with research conducted by Wahyuningtyas (2010) found that information on cash flow values has no effect in predicting financial distress conditions.

\section{CONCLUSION AND RECOMMENDATIONS}

This study aims to examine the effect of financial ratios, namely liquidity ratios, profitability, leverage and operating cash flows on the condition of financial distress companies that are on the Indonesia Stock Exchange (IDX) in 2013-2017. From the total population, 323 were obtained as samples in this study. Based on the results of data analysis and discussion, conclusions can be drawn as follows:

- From the results of data analysis it can be concluded that the independent variable that is the most important and considered by each user and recipient of information is the variable profitability ratio. Where the ratio has a beta value $(B)$, error standard and value greater than other variables and has a smaller significant value compared to other variables. 
- The liquidity ratio measured using the current ratio (CR) has a negative effect on corporate financial distress on the Indonesia Stock Exchange (IDX) in 2013-2017 with a significant level of 0.008 greater than the value of $\alpha(<0.05)$. Thus the higher the value of liquidity of a company will increase the value of the company and will provide a positive signal for the capital market so that the company will not experience financial distress.

- Profitability ratio as measured by Return On Assets (ROA) has a negative effect on the condition of financial distress with a significant level of 0,000 on the condition of corporate financial distress in the Indonesia Stock Exchange (BEI) in 2013-2017 which is indicated by sig values from the results of logistic regression analysis found that sig ROA is smaller than $\alpha(<0.05)$. Thus the greater the value of profitability produced by the company will increase the value of the company and provide a positive signal for the capital market so that the company will not experience financial distress.

- The ratio of financial leverage as measured by Debt to Equity Ratio (DER) has a negative effect on the condition of corporate financial distress in the Indonesia Stock Exchange (IDX) in 2013-2017 with a significant level of 0.004 smaller than the value of $\alpha(<0.05)$. Thus the higher the value of financial leverage owned by a company will reduce the value of the company and provide a negative signal for the capital market so that it will cause the company to experience financial distress.

- The operating cash flow ratio (AKO) does not affect the company's financial distress on the Indonesia Stock Exchange (IDX) in 2013-2017 with a significant level of 0.373 greater than the value of $\alpha(>0.05)$.

Based on the results of research, analysis, and discussion that has been described in the previous chapter regarding the effect of financial ratios, namely liquidity ratios, profitability, leverage and operating cash flows on the condition of corporate financial distress in the Indonesia Stock Exchange (BEI) in 2013-2017, suggestions can be taken as follows:

For the Company:

- Companies should be able to analyze financial distress conditions as early as possible from the company's financial ratio analysis to help company managers make new policies to prevent financial distress.

- The company management need to pay more attention to the financial leverage ratio in carrying out corrective actions, where this ratio proved to have a positive and significant effect in predicting financial distress and profitability and operating cash flow ratios, where the ratio has a negative minimum value which will cause the company to experience conditions financial distress.

For Researchers:

- Further research is expected to be able to use a more different combination of ratios and not only focus on financial ratios as a measure to predict the company's financial distress on the Indonesia Stock Exchange, but also use other factors that can predict financial distress conditions such as external factors, among others inflation, interest rates, exchange rates and economic growth.

For Practitioners:

- The results of this study are expected to provide input and help investors in investing their capital by looking at the condition of the company through financial ratios, especially financial leverage in carrying out corrective actions, where this ratio has a positive and significant effect in predicting financial distress and profitability and cash flow ratios operation, where the ratio has a negative minimum value which will cause the company to experience financial distress, so investors are not wrong in investing their capital into the company.

- It is expected that investors and potential investors to view financial statements are used as a basis in making decisions to invest in companies, especially financial leverage in carrying out corrective actions, where this ratio is proven to have a positive and significant effect in predicting financial distress conditions. 


\section{REFERENCES}

1. Almilia, L. S. 2006 'Prediksi Kondisi Financial Distress Perusahaan Go- Public Dengan Menggunakan Analisis Multinomial', Jurnal Ekonomi and Bisnis, XII(1), pp. 1-26.

2. Almilia, Luciana Spica and Kristijadi. 2003. Analisis Rasio Keuangan Untuk Memprediksi Kondisi Financial Distress Perusahaan MAnufaktur Yang Terdaftar di Bursa Efek Jakarta. Jurnal Akuntansi and Auditing Indonesia. Vol. 7 No.2 2003.

3. Altman, E.I. 1968 'Financial Ratio, Discriminant Analysis, and the Prediction of Corporat Bankruptcy', The Journal of Finance, September (25). Vol. XXIII No. 4.

4. Andre, Orina. 2013. Pengarus Profitabiitas, Likuiditas and Leverage dalam Memprediksi Financial Distress pada Perusahaan Aneka Industri di Bursa Efek Indonesia. Jurnal Universitas Padamg. Vol. 1 No. 12013.

5. Atika, 2013 'Pengaruh Beberapa Rasio Keuangan Terhadap Prediksi Kondisi Financial Distress (Studi Pada Perusahaan Tekstil and Garmen yang Terdaftar di Bursa Efek Indonesia periode 2008-2011)', Jurnal Administrasi Bisnis, pp. 1-11.

6. Darsono and Ashari. 2005.Pedoman Praktis Memahami Laporan Keuangan.Andi. Yogyakarta.

7. Endang Afriyeni \& Jumyetti. 2016. Pengaruh Rasio Keuangan dalam Memprediksi Kondisi Financial Distress pada Perusahaan Perbankan yang Terdaftar di Bursa Efek Indonesia. National Conference of Applied Sciences, Engineering, Business and Information Technology. Politeknik Negeri Padang, 15 - 16 Oktober 2016.

8. Evanny, Indri Hapsari. 2012. Kekuatan Rasio Keuangan Dalam Memprediksi Kondisi Financial Distress Pada Perusahaan Manufaktur di Bursa Efek Indonesia. Jurnal Dinamika Manajemen. Vol. 3 No. 22012.

9. Grice, J. S and Dugan, M.T. 2003. Re-estimations of Zmijewski and Ohlson Bankruptcy Prediction Model. Journal of Advance in Accounting Vol 20:77-83. Elsester, Ltd.

10. Harahap, Sofyan. 2013. Analisis Kritis Atas Laporan Keuagan. Yogyakarta: Raja Grafindo Perada.

11. Hidayat, Muhammad Arif and Meiranto, Wahyu. 2014. Prediksi Financial Distress Perusahaan Manufaktur di Indonesia. Jurnal Akuntansi Universitas Diponegoro. Vol. 3 No. 32014.

12. Husein, M., F., and Pambekti, G. T. (2014). "Precision of the models of Altman, Springate, Zmijewski, and Grover for predicting the financial distress". Journal of Economics, Business, and Accountancy Ventura. Vol 17 No 3. https://doi.org/10.14414/jebav.14.1703010

13. Husnan, Suad. 2014. Manajemen Keuangan Teori and Penerapan (Keputusan Jangka Panjang). Edisi Keempat. Yogyakarta: BPFE.

14. Imam Ma'ud Reva Maymi Srengga (2011) 'Analisis Rasio Keuangan Untuk Memprediksi Kondisi financial distress Perusahaan Manufaktur yang Terdaftar di BEl', Program Studi Akuntansi Fakultas Ekonomi Universitas Jember.

15. Irham Fahmi, 2015, Analisis Laporan Keuangan, Alfabeta, Bandung

16. Jogiyanto, Hartono. 2000. Teori Portofolio and Analisis Investasi. Edisi Kedua. Yogyakarta: BPFE UGM.

17. Kalimah, Sri. 2017. Pengaruh Profitabilitas, Likuiditas and Leverage Dalam Memprediksi Financial Distress (Studi Empiris Pada Perusahaan Manufaktur yang Terdaftar di BEI Periode 2009-2013). Jurnal Akuntansi and Ekonomi. Volume 2 No 12017.

18. Kasmir, 2016, Analisis Laporan Keuangan, PT Raja Grafindo Persada, Jakarta.

19. Kasmir. 2010. Analisis Laporan Keuangan. Jakarta; PT. Rajawali.

20. Kasmir. 2012. Analisis Laporan Keuangan. PT. Raja Grafindo Persada. Jakarta

21. Layyinaturrobaniyah and Dewi, K., R. 2017. "Analisis Prediksi Financial Distress

Berdasarkan Model Altman and Zmijewski Pada Perusahaan Manufaktur Yang Terdaftar

Di Bursa Efek Indonesia". Jurnal Ekonomi and Bisinis Terapan. Vol 13 No 1.

22. Munawir, S. 2004. Analisis Laporan Keuangan. Yogyakarta: Liberty. 
23. Noviandri, Tio. 2013. Peranan Analisis Rasio Keuangan Dalam Memprediksi Kondisi Financial Distress Perusahaan Sektor Perdagangan. Jurnal IImu Manajemen. Volume 2 Nomor 4 Oktober 2014.

24. Nurcahyono. 2014. Analisis Rasio Keuangan untuk Memprediksi Kondisi Financial Distress. Management Analysis Journal, 3.

25. Platt, H., and M. B. Platt. 2002. "Development of a class of stable predictive variable: the case of bankruptcy predictions". Journal of Business Finance and Accounting. Vol. 17: 31-51.

26. Robert Odero Otom (2014) 'Predicting Financial Distress Using Financial Ratios In Companies Listed In Nairobi Stock Exchange (2003-2011)', United States International University- Africa.

27. Sidik, Jamilah. 2003. 'Pengaruh Rasio Keuangan pada Kualitas Laba, Tesis, Magister Management', Universitas Gajah Mada, Jogjakarta.

28. Sigit, R. 2008. 'Pengaruh Rasio Likuiditas, Financial Leverage and Arus Kas Untuk Memprediksi Financial Distress Pada Perusahaan Real Estate And Property yang Terdaftar Di BEJ tahun 2004-2005', Skripsi Fakultas Ekonomi UNS.

29. Srikalimah. 2017. 'Pengaruh Profitabilitas, Likuiditas and Leverage Dalam Memprediksi Financial Distress', Jurnal Akuntansi \& Ekonomi FE. UN PGRI Kediri, 2(1), pp. 43-66.

30. Subramanyam. 2010. Analisis Laporan Keuangan, Edisi 8, Jakarta: Salemba Empat.

31. Wahyuningtyas, Fitria. 2010. Penggunaan Laba and Arus Kas Untuk Memprediksi Kondisi Financial Distress (Studi Kasus Pada Perusahaan Bukan Bank yang Terdaftar di Bursa Efek Indonesia Periode Tahun 20052008.Skripsi.Fakultas Ekonomi, Univeritas Diponegoro.

32. Widarjo, W. and Setiawan, D. 2009. 'Pengaruh rasio keuangan terhadap kondisi financial distress perusahaan otomotif', Jurnal Bisnis and Akuntansi, 11(2), pp. 107-119. doi: 10.1016/j.intele.2017.03.006.

33. Wijarnarto, H. and Nurhidayati, A. 2016. 'Pengaruh Rasio Keuangan Dalam Memprediksi Financial Distress Pada Perusahaan Di Sektor Pertanian and Pertambangan Yang Terdaftar Di Bursa Efek Indonesia (Hery\&Anik) 86', 3(1), pp. 86-105. 